PART 2

War, Gender and Nation 
Elif Akşit - 9789004305809 Downloaded from Brill.com04/26/2023 09:34:18AM via free access 


\title{
Being a Girl in Ottoman Novels ${ }^{1}$
}

\author{
Elif Akşit
}

The difficulty of conceptualizing girlhood has led to the under-representation of girls in scholarly writing. In this chapter, I tackle this difficulty by focusing on how girls are depicted in Ottoman novels, exploring the interrelationship between the processes of becoming a nation, as formulated and reformulated by the novel, and the process of becoming as revealed in girls' lives. In other words, the birth of the novel, the birth of the nation and the birth of 'the girl' can be considered as part of the same broader development.

The close links between gender and nationalism and the ways in which nationalist discourse instrumentalized women's bodies in order to create soldiers to fight for the nation have been explored in various contexts in recent decades. $^{2}$ However, the centrality to this endeavour of girls and their stories of becoming has been less explored. ${ }^{3}$ This chapter demonstrates this centrality by considering how male and female authors of the late Ottoman period tell stories of girls in the process of becoming a woman, and of the feminine as a project of becoming. ${ }^{4}$ I draw on examples from the works of Namik Kemal, Ahmet Mithat, Fatma Aliye, Halide Edip, Reşat Nuri, Samipaşazade Sezai and

1 Many thanks for the help of Ben Fortna, Alev Özkazanç, Ezgi Sarıtaş and Firdevs Canbaz.

2 See Anna Davin, "Imperialism and Motherhood," History Workshop, 5, 1978, 9-65; Seth Koven and Sonya Michel (eds), "Womanly Duties: Maternalist Politics and the Origins of Welfare States in France, Germany, Great Britain, and the United States, 1880-1920," American Historical Review, 95 (4), 1990, 1092-1093;" id., Mothers of a New World: Maternalist Politics and the Origins of Welfare States (London: Routledge, 1993); Ida Blom, Karen Hagemann and Catherine Hall (eds), Gendered Nations: Nationalisms and Gender Order in the Long Nineteenth Century (Oxford: Berg Publishers, 200o); Ayşe Gül Altınay, The Myth of the Military-Nation:Militarism, Gender and Education in Turkey (New York: Palgrave Macmillan, 2004); Beth Baron, Egypt as a Woman: Nationalists, Gender, and Politics (Berkeley: University of California Press, 2005).

3 I have developed the theme of girls as future mothers in my PhD thesis: Elif Akşit, "Girls' Education and the Paradoxes of Modernity and Nationalism in the Late Ottoman Empire and the Early Turkish Republic." Binghamton University, Department of History, 2004.

4 See Ian Buchanan and Claire Colebrook (eds), Deleuze and Feminist Theory (Edinburgh: Edinburgh University Press, 200o); Rosi Braidotti, "Becoming Woman: Or Sexual Difference Revisited," Theory, Culture \& Society, 20 (3), 2003, 43-64; Patty Sotirin, "Becoming-woman," In Charles J. Stivale (ed.), Gilles Deleuze: Key Concepts (Durham, U K: Acumen, 2005) 98-109.

(C) ELIF AKŞIT, 2016 | DOI 10.1163/9789004305809_006

This is an open access title distributed under the terms of the Creative Commons Attribution- 
Halit Ziya ${ }^{5}$ and I argue that while male authors either idealized or criticized girls and the conditions they had to bear, women's writings on girls were lines of flight from these tendencies of instrumentalization into real stories of becoming. ${ }^{6}$ Male writers also used girls' bildungsroman in encompassing, recreating and rewriting womanhood. ${ }^{7}$ I conclude that it is in fact this genuine search for becoming that the nationalist aspirations for meta-narratives depended upon, and that women's writing provides us with more realistic stories of becoming than those of male writers, whose work remains at the instrumental level of educating the public to be nationalists. Overall, Ottoman novels seem to have a fixation on girls; slave girls in particular stand out as powerful figures symbolizing everything that is wrong with the Empire, especially in men's novels.

It is quite hard to conceptualize 'the girl' within childhood. Her being a girl, and not just a child, is the point where she starts to be told to behave in certain ways: either like a child, like a boy or like a woman. But at the same time she is considered to be a woman and is asked to conceal herself and to serve like a woman; she is harassed and becomes a magnet for the male gaze. In the story of the girl lies the history of modernity, even more than is found nationalism,

5 A wider array of novels written in the different languages of the Ottoman Empire could be compared in future studies.

6 This concept is explained in Gilles Deleuze and Felix Guattari, A Thousand Plateaus: Capitalism and Schizophrenia II, translated by Brian Massumi (Minneapolis: University of Minnesota Press, 1987), 9-10.

7 The feminist usage of Deleuze and Guattari's theory, and especially the term "becomingwoman," is a much debated issue. Deleuze and Guattari both critique and affirm feminism via the term "becoming woman," underlining the necessity of feminist politics, women "winning back their own organism, their own history, their own subjectivity," but saying that this subject (of feminism) functions by "drying up a spring or stopping a flow." They find Nietzchean definitions of resentment and the will to power in this trait of feminism, where the telling of untold stories feed rather than abolish resentment and the road to empowerment becomes a way to the will to power:

It is, of course, indispensable for women to conduct a molar politics, with a view to winning back their own organism, their own history, their own subjectivity: "we as women [...]" makes its appearance as a subject of enunciation. But it is dangerous to confine oneself to such a subject, which does not function without drying up a spring or stopping a flow. The song of life is often intoned by the driest of women, moved by ressentiment, the will to power and cold mothering.

DELEUZE and GUATTARI, $A$ Thousand Plateaus, 276

However, in exploring alternative truths, other paths also open, such as the case of women telling girls' stories and freeing the girl figure - and thus themselves—-from being used or being killed in her passage to womanhood, as was the case in the prior examples of novel in the Ottoman Empire. 
but 'the girl' is so hard to define, because she carries many stories with her all at once. These powers are the same powers that make her invisible, that cause her to be harassed and to remain silent. Many men, many projects, feed from these powers but the girl remains invisible. It is easy to justify this invisibility: she is not a child, she is not a woman-however, at the same time, she is both a child and a woman.

In order to better pursue this multi-faceted identity, in the following section I focus on the changing dynamics of family and education in Ottoman girls' lives. I then discuss how the creation of a new literature, the new idea of nationalism and the concept of the new girl coincide, drawing on literature and philosophy to evaluate how novels develop the interrelationship between literature, politics and gender, and to explore the ways in which the inbetweenness and power of girlhood is manipulated and reflected in the Ottoman novel.

\section{The Nineteenth Century and the Rise of the Girl}

The family is an appropriate starting point in this search; however, although the family and the household as centres of trade and intellectual life in the Ottoman Empire are significant aspects of Ottoman historiography, the place of women has been under-researched. Further, although 'the birth of the girl' concerns all social classes, studies on the family have focused predominantly on the religious practices, education and daily lives of elite women. ${ }^{8}$ Yet starting with the family is important, as the passage to the public spheres of education and media have their beginnings in the harems. I have previously argued that the public education programs for girls initiated by the Ottoman state in the early nineteenth century had their roots in harem education; existing forms of household education were transferred to the public education curriculum, and thus girls' education in the Empire represented a continuum between the harem system and the new technical schools. Including the harem in the analysis of public education practices also allows for a better understanding of women's roles in the transformation from private to public education.

8 The few examples that take families as an important unit of analysis include: Beshara Doumani, Rediscovering Palestine: Merchants and Peasants in Jabal Nablus 1700-1900 (Berkeley: University of California Press, 1995); Hala Fattah, The Politics of Regional Trade in Iraq, Arabia, and the Gulf, 1745-19oo (Albany: State University of New York Press, 1997); Thabit Abdullah, Merchants, Mamluks, and Murder: The Political Economy of Trade in Eighteenth Century Basra (Albany: State University of New York Press, 2001). 
Literature is a source for women and girls in the private sphere as well as the public sphere, with the authors Fatma Aliye and Halide Edip providing details that should be evaluated carefully.

The elite families that were bases for women's networks were deeply embedded in the political life of the Ottoman Empire in the eighteenth and nineteenth centuries. ${ }^{9}$ Kinship relations were widened to include the service providers of the household, meaning that the elite structure of the family and the different forms of education it provided encompassed different classes: less wealthy family members, service providers, high-ranking slaves, low-ranking slaves, etc. Elite households were thus centres for the systematized education of girls before the establishment of girls' public schools. Older women educated younger women, and educated women occupied higher ranks in these hierarchies. ${ }^{10}$ Thus, pursuing the intellectual roots of women's education in families promises to provide an alternative history of education in the Ottoman Empire.

The subjects taken up in harem education consisted of sewing, embroidery, playing the harp and singing, and memorization of customs and ceremonies. ${ }^{11}$ The harem transformed greatly over the eighteenth and nineteenth centuries, and this became a subject of discussion among Ottoman intellectuals in the nineteenth century. The new elites that emerged in the eighteenth century replicated the imperial practices of education and the Ottoman household: their homes became more like the imperial harem, and this resemblance challenged its authority at the same time. While the new elites started to raise their members through these households, the state, too, initiated new ways of public education throughout the nineteenth century. Public schools for girls were initiated from 1850 onwards. The practices of public education in these schools incorporated the segregated nature and practices of harems. The first modern form of widespread girls' public schooling was the girls' maturation schools [Rüştiyes] that were

Fanny Davis, The Ottoman Lady: A Social History from 1718 to 1918 (New York: Greenwood Press, 1986); Fanny Davis's style recalls that of Lucy Garnett,who was also a freelance writer, or, to a certain extent Grace Ellison, a British woman who lived in Ankara and wrote orientalist accounts of women in Turkey. Although not listed in her sources, Demetra Vaka, a Greek-American woman who wrote about the harem based on her experiences, also belongs to her list of memoir-related accounts of the harem (Davis,xi). See Grace Mary Ellison, An Englishwoman in a Turkish Harem (London: Methuen and Co., 1915); Lucy Mary Jane Garnett, The Women of Turkey and Their Folklore (London: D. Nutt, 1890-1891); Demetra Vaka Brown, Haremlik (Boston: Houghton Mifflin Company, 1909).

10 Elif E. Akşit, "Harem Education and Heterotopic Imagination," Gender and Education, 23 (3), 2011, 299-311.

11 Jane Hathaway, The Politics of Households in Ottoman Egypt: the Rise of the Qazdagli (Cambridge: Cambridge University Press, 1997). 
initiated as early as $185^{8}$, during the reforming atmosphere of the Tanzimat era. Soon after, in 1865, industrial schools for girls [İnas Sanayi Mektepleri] were established simultaneously with those for boys, ${ }^{12}$ the first in an old clothes factory for the army in Russe (now in Bulgaria) where orphan girls were employed and educated. Others came into being shortly after this, particularly in Istanbul. In 1873, thefirstgeneration of students graduatedfrom teachers' schools [Darülmuallimat], and women started teaching in various established schools for girls.

Most of the girls came to the industrial schools as teenagers and without any prior education; in their first year, classes on speaking techniques and reading and writing provided a formative education, and students were instructed in a variety of topics such as general education, science and Persian and Arabic languages. However, the schools also replicated certain educational models from the elite harems, transmitting them into the arena of industrial production. For example, the core curriculum included religion, embroidery and music, signifying continuity between household and public education in practices of modernization; the study of the Quran suggested that there was still an Islamic emphasis to education, just as in the harems. However, as regards music, the inclusion of piano lessons - even in the first girls' industrial school in Russe-demonstrated how the music classes that were transferred from the nineteenth century households were signs of Westernization. Similarly, supporting classes on mathematics, ethics, administration, geography, history and drawing emphasized the scientific aspect of education and were new additions to girls' public and private education. Girls' industrial schools thus transferred patterns of education from the households, but they also partially transformed these patterns..$^{13}$

It is interesting to see similar patterns emerge among Western girls and Ottoman girls at the turn of the century, a time when both worklife outside the house and education became more common for the latter. ${ }^{14}$ Three qualities distinguish 'the new girl' in the late nineteenth and early twentieth centuries. Firstly, the new girl displays an urban character, as the public schools opened in the major cities and became widespread. Secondly, girls were regarded as women and they were obliged to be properly covered and to be educated only by women, unless their instructors were 'aged and well-behaved' men.15 However, education and work placed them in a new category of women,

12 Leslie Peirce, The Imperial Harem: Women And Sovereignty In The Ottoman Empire (New York: Oxford University Press, 1993), 140.

13 Peirce, Imperial Harem.

14 Philippe Ariès, A Social History of Family Life (London: Jonathan Cape, 1962), 53.

15 Marie Florine Bruneau, "Learned and Literary Women in Late Imperial China and Early Modern Europe," Late Imperial China, 13 (1), 1992, 160. 
characterized by delayed marriage and motherhood. The new trends in girls' education also socialized them not only as agents of modernity, but also as future teachers. Thus, the already existing ambivalence around the concept of the girl was in a way institutionalized with the spread of education for girls. The third quality relates to class: the new girl, especially that the Industrial Schools aimed to create, was ultimately a working girl, and therefore differed from the wealthier students of the elite schools. ${ }^{16}$ This portrait of the workingclass 'new girl' can be found in the newspapers and journals of the era.

\section{Journals}

The place in journals of not only girls but also children in general is another neglected issue in the history of the girl, and ${ }^{17}$ the invisibility and power of girlhood can both be traced in Ottoman journals. According to Sally Mitchell, the new girl's readership of journals in England both unites girls in education and worklife and distinguishes 'the girl' as a separate category; similarly, urban Ottoman girls, through becoming students, acquired new identities and in Istanbul became consumers of journals. ${ }^{18}$

Children's magazines in the Ottoman Empire have as long a history as women's magazines, usually taken as having begun in 1869 , when the newspaper Mümeyyiz issued a supplement for children. After this, a dozen other journals also came into existence. ${ }^{19}$ The lifespan of these journals rarely exceeded one or two years, and they were very rarely published outside Istanbul. Çocuklara Mahsus Gazete commenced in 1896; after a short break, in 1904, Çocuk Bahçesi, and five years later, Arkadaş and Çocuk Dünyası, owned by Leon Lütfi, were published. Çocuk Duygusu, with Baha Tevfik as the chief columnist, in 1913-1914 changed the previous format of children's journals by publishing comics. ${ }^{20}$

16 Their case was usually the opposite, as these women contributed to works that are known to belong to famous men. Fatma Aliye, Hayattan Sahneler (Levayih-i Hayat) (Istanbul: Boğaziçi Üniversitesi Yayınevi, 2002 [1897-1898]), xii; Bruneau, "Learned and Literary Women," 165, 167-168.

17 Yahya Akyüz, "Osmanlı son döneminde kızların eğitimi ve öğretmen Faika Ünlüer'in yetişmesi ve meslek hayatı." Millì Eğitim Dergisi 143 (1999), 19.

18 Sally Mitchell, The New Girl: Girls' Culture in England 1880-1915 (New York: Columbia University Press, 1995).

19 I have introduced this discussion in chapters three and four of "Girls' Education."

20 Mehmet Azim, “Çocuk Bahçesi Dergileri," Müteferrika, 19, 2001, 143-179; Bülent Varlı, “Tanzimat ve Meşrutiyet Dergileri," Tanzimat'tan Cumhuriyet'e Türkiye Ansiklopedisi (İstanbul: İletişim Yayınları, 1985), 123. 
Meanwhile more journals with education and nationalism as the main theme came into existence in the second constitutional era.

Three of these journals were children's versions of women's journals: Çocuklara Mahsus Gazete (1897) of Hanımlara Mahsus Gazete, Çocuk Duygusu (1913) of Kadınlık Duygusu and Çocuk Dünyası (1913) of Kadınlar Dünyası. Çocuklara Mahsus Gazete gave Hanımlara Mahsus Gazete as its mailing address, but did not acknowledge the latter as its inspiration despite the manifest similarity in the formats of the two journals. The introductory article of the first issue was titled "The Humanist Feelings of a Child," ${ }^{21}$ and told the story of a seven- or eight-year-old boy who went to the coffeehouse to read with his father. The writer of the article, who was also the journal's publisher, expressed pity for this young child. Having to read journals that were designed for adults, the boy constantly had to ask his father the meanings of the Persian words in the novels that the newspapers published. This introduction highlights two elements that prevailed in children's journals until the last ten years of the Ottoman Empire: first, that the journals' muse was unquestionably the boychild, and, second, that the prevailing household education that these boys went through should be critiqued.

This discourse on the inappropriateness of household education as well as of adult texts for children had begun a decade before the publishing of Çocuklara Mahsus Gazete in 1897. Benjamin Fortna observes that children's books started to be published in the Ottoman Empire as early as the mid-188os; he gives the book Çocuklara İstifade [For the Benefit of Children] as the primary example of the disappointment of a child with the small black scribbles that books contained. This disappointment was increased by the fact that learning to read was a difficult experience, starting with the reading of the Quran in Arabic ${ }^{22}$ and of texts that were filled with unknown words. Thus, it was implied, a child could not be educated in reading and writing at home. The school was deemed to be an absolutely necessary institution in boys' and girls' education. ${ }^{23}$ The discourse on the necessity of schools rejected the importance of household education, presenting the image of an illiterate mother unable to teach reading and writing skills to her child.

21 Baha Tevfik, "The Humanist Feelings of a Child" [Bir Çocuğun İnsaniyetperveranesi], Çocuklara Mahsus Gazete, 13 Şubat 1312/ 23 Ramazan 1314 [25 February 1897], 1.

22 The Quran was actually easier to read as it had spelling marks, and unlike the Ottoman script, which is shorthanded, every letter is openly spelled in the Quran.

23 Benjamin C. Fortna, "Learning to Read in the Late Ottoman Empire and Early Turkish Republic," Comparative Studies of South Asia, Africa and the Middle East, 21 (1-2), 2001, 34-41. 
The women's journals drew upon Western and other feminisms, and the dynamic character of their readers had the potential to challenge the status $q u o$. However, the discourse on children functioned by ignoring its feminist origins in the Ottoman press, as well as by rejecting the importance of household education. Although they repeated the formats and used the equipment of women's journals, children's journals lacked the critique of the former. The common goal of all children's journals was education, and one means used was children's contests. Such contests compared and contrasted the success and physical characteristics of children, as well as their parent's wealth and status; one example appears in Mahasin (1908-1910), a journal that had consistently employed women writers such as Zühre Hanım, Emine Semiye Hanım and Zekiye Hanım, as well as Halide Edip (writing as Halide Salih, and discussed further below). The contest placed importance on detailed descriptions of the children's fathers' occupations and the districts in which they resided. ${ }^{24}$

Baha Tevfik, as the publisher of Çocuk Duygusu, sought to convey rules of courtesy and respect to its young readers, through original means such as printing details on cards. The first issue also tells the story of a young revolutionary during the French Revolution ${ }^{25}$ who is nearly killed and then decides to disassociate himself from revolutionary activities. In this way, Tevfik presents the French Revolution as something interesting for the children, and from the point of view of a revolutionary, while at the same time condemning it.

Çocuk Duygusu also illustrates a shift away from an emphasis on boys. As a start, boys and girls who wrote to the journal were referred to by the names of their schools. From the sixth issue on, Selim Sirrı composed long pieces that were written for his daughters but addressed to all girl readers. In one of his essays, dating from 1913 and presented in the form of a dialogue with his daughters, he first defined the word ' $k z$ ' as a Turkish girl, and then as a philosophical being. ${ }^{26}$ When he asked his daughters what they were, they answered, as good girls should: "I, dear daddy, am Turkish, am a Muslim. I am a girl, who is eight years old." This was the answer that he had wanted, so he advanced the discussion and asked what it was that distinguished them as girls from stones, trees, animals and birds. Upon their silence, he answered his own question by introducing a philosophy of humanity to the word ' $k z$,' saying that they were ontological beings beyond their Muslim and Turkish identities, and ending the

24 Mahasin, Numara 1 2, Teşrin-i Sani 1320 [15 November 1904]; Ylldız Akpolat-Davud, "II. Meşrutiyet'te Toplumda Kadına Başat Rol Vermeyen: Kadın Dergisi Mahasin," Tarih ve Toplum, 156, Aralık 1996, 362-367.

25 Baha Tevfik, "Fransa İhtilalinden bir Sahife," Çocuk Duygusu, 1, 6 Haziran 1329 [1913], 1.

26 Selim Sırrı, “Kızlarıma Öğütlerim: Ben Neyim,” Çocuk Duygusu, 19, Temmuz 1913, 1. 
conversation with this monologue that pointed towards their potential powers and complex being.

Sirrı was well aware that childhood had been perceived as synonymous with boyhood and that the spread of girls' education could change this misconception. He was also aware that he was the first to introduce this discussion into the genre of children's journals. ${ }^{27}$ Thus, the inclusion of pictures of girls on the cover page rather than boys supported his essays, and his essays on his daughters constituted the main body of the issues that in which they appeared. Further, the very first issue was printed in red ink, underlining the importance of the subject. Having thus guaranteed attention, he not only introduced a discussion relating to girlhood but also sought to manipulate popular views. These views were represented by his very young daughters, answering his questions on their girlhood as "I am a Muslim girl," or "I am a Turkish girl." Although he did not provide a solid alternative to these conceptions, he hinted that girlhood was beyond these identities. As a result, the word ' $k z$ ' started to be observed in the journal from the first page, ${ }^{28}$ and the girl introduced to the Ottoman world of printed journals beyond her Islamic and Turkish identities in 1913.

\section{Context for the Rise of the Novel}

Education was the most important aspect of Tanzimat reforms that began in 1839, and that marked a new kind of relationship between the Empire and the new world powers. In this new setting, the Ottoman state machine needed a Western-oriented but primarily Muslim bureaucratic class. The young men that the state systematically sent to France for education after 1789 were just a handful at first; these students, now distinct statesmen, or pashas, became the architects of the reforms, including the resulting new education system. However, while this system was on its way to raising a whole new bureaucracy, the void was in the meantime filled with imitation Tanzimat pashas: ${ }^{29}$ the Tanzimat literature is filled with pseudo-westerner Ottomans, whose imitation of the pashas derived from denying their own Ottoman-Islamic identities rather than any substantial knowledge of the West. Their belittling of Islamic identities, traditional lifestyles and family relations was criticized by the Young Ottomans. ${ }^{30}$

\footnotetext{
27 Selim Sırrı, “Türk Kızının Öğüdü,” Çocuk Duygusu, 6, 1912, 1; id. “Kızlarıma Öğütlerim.”

28 Ibid.

29 Akşit, "Harem education."

$30 \quad$ Ibid.
} 
Although it seemed that these types of bureaucratic personalities were going to be replaced once the newly educated generations were raised, this proved not to be the case; the mindset of the pseudo-westerner Ottomans predominated over that of the first generation of Ottomans to acquire a Westernstyle education in the Ottoman Empire. This new generation was known for its harsh critique of the Tanzimat mentality, both of the pashas and of the false pretenders who formed the bureaucratic class. As a result, they were marginalized and unable to find employment in the bureaucracy themselves, and because of this their critique grew harsher. Instead, they channelled their language, writing and analytic skills into journalism and literature. ${ }^{31}$

The avant-garde novelists Namık Kemal (1840-1888) and Ahmet Mithat (1844-1912) came out of this atmosphere, and their novel-writing and publishing efforts aimed to empower lower- and middle-class urbanites like themselves. Namık Kemal was born into a family of state officials and had a high-level of education from private tutors in his governor grandfather's home, whereas Ahmet Mithat was born into a poor family in Istanbul and attended the Rüsdiye, the new secular school that was a product of centralization and modernization processes in the Empire. Ahmet Mithat also taught himself, and learned Arabic while working as an apprentice in a spice-shop at in the local market. He then followed the Young Ottoman way pioneered by Namı Kemal, becoming a well-known journalist and writer. Thus, he was a product of the struggle among mindsets caused by nineteenth century reforms.

These authors saw themselves in the role of a nourishing 'mother,' to young women more so than to young men. Ahmet Mithat appears to be 'becoming a woman' in his aspiration to turn girls into new kinds of women, in the sense described by Deleuze and Guattari:

The rise of women in English novel writing has spared no man: even those who pass for the most virile, the most phallocratic, [...] in their turn continually tap into and emit particles that enter the proximity or zone of indiscernibility of women. In writing, they become-women. ${ }^{32}$

In this fashion, Ahmet Mithat instrumentalized 'becoming woman' to be able both to flirt with the Empire, and at the same time to imagine alternative

31 See Erik J. Zürcher, Turkey: A Modern History (London: I.B. Tauris, 2004). See also Şerif Mardin, The Genesis of Young Ottoman Thought: A Study in the Modernization of Turkish Political Ideas (Syracuse, NY: Syracuse University Press, 2000); Itzchak Weismann and Fruma Zachs (eds), Ottoman Reform and Muslim Regeneration (London: I.B. Tauris, 2005). 
futures, although this early novelist's know-it-all approach towards young women also reveals the limitations of this complicated position from early on.

Fatma Aliye (1862-1936) was Ahmet Mithat's student, and he opened the way for her to become the first female Ottoman novelist, in the interstices between the harem curriculum and the scientific emphasis of public education. His desire to become a mother appears in its most obvious form in his biography of her, Bir Muharrire-i Osmaniye'nin Neşeti [The Birth of an Ottoman Woman Writer $].^{33}$ In this work, it is he who gives birth to the first Ottoman woman writer, as her educator, her manager and co-author. ${ }^{34}$ However, Fatma Aliye, as the first Ottoman woman writer and one of the first Ottoman novelists, went beyond Ahmet Mithat's influence and found her own voices in her novels Ref'et (1898), Udi (1899), Muhadarat (1892) and Enin (1910). She reflected the concerns of a swelling population of educated women in her novels, with a focus on urban, educated and/or poor girls.

Like the Young Ottomans, Fatma Aliye was also active in newspapers and journals, and she wrote extensively about girls in of all ages and young women in relation to marriage, education, poverty and slavery: she was a prominent contributor to Hanımlara Mahsus Gazete, and as the journal gained considerable popularity it catalysed a new kind of relation to mainstream politics for women. ${ }^{35}$ Fatma Aliye rejected the Orientalist 'feminist' viewpoint that declared a subordinate place for women in Muslim societies, and she avoided using the Western terms feminism and feminist: her struggle was for equality with Western women, as well as for fair collaboration with men. However, she promoted the core aspects of the concept of feminism, and a conceptual history of the women's movement in Turkey starts with her.

In the subtle ways that Fatma Aliye imagined and realistically depicted alternative ways for women and girls, I will show that her persistence in the girl

33 Ahmet Mithat, Bir Muharrire-i Osmaniye'nin Neşeti (İstanbul: İsis, 1998 [1893]).

34 In Fatma Aliye, Hayal ve Hakikat: Bir Kadın ve Ahmet Midhat (İstanbul: Yıldız Üniversitesi Basım Yayın, 2005 [1892]). Hülya Adak emphasizes how Ahmet Mithat keeps talking about himself even though it is Fatma Aliye's biography in The Birth. See Hülya Adak, "Gendering Biography: Ahmet Mithat (on Fatma Aliye) or the Canonization of an Ottoman Male Writer," Querelles, 10, 2005, 189-204.

There were other influential women, such as Halide Edip, Fatma Aliye's sister Emine Semiye and Müfide Ferit, who also wrote novels and contributed to newspapers; their contributions in different media deserve to be evaluated much further than they have been up until now. However, for the purposes of this chapter I focus only on Fatma Aliye and Halide Edip, due to their emphasis on the girl and the thematic continuities with the other authors under discussion. 
figure - continued by Halide Edip and Halit Ziya-is a line of flight. ${ }^{36}$ In Deleuze and Guattari, too, it all starts with the girl: "becoming-woman" describes the girl herself. The body is first stolen from the girl. ${ }^{37} \mathrm{Her}$ being a girl dissects boundaries, and thus attracts extra interference and regulation. Yet she remains "an abstract line, or a line of flight. Thus girls do not belong to an age group, sex, order, or kingdom: they slip in everywhere, between orders, acts, ages, sexes." 38

This is so for the girls in Fatma Aliye's and Halide Edip's novels: these women's stories of becoming woman describe but also empower their girlhood. ${ }^{39}$ Halit Ziya stands in between these male and female writers: his ultimate girl character remains a child, and his stories of becoming woman destroy everyone around. He is the only one among the male writers discussed below who succeeded in 'becoming woman.' With these examples, I will try to explore the ways in which the in-betweenness and power of girlhood is manipulated and reflected in the Ottoman novel.

\section{The Slave Girl and the Birth of the Ottoman Novel}

The journals of the second constitutional era were publishing novels in serialized form. By 1913, girls with Islamic and Turkish identities, as students and slaves, as beholders of beauty and ugliness and as pathetic and powerful were introduced into the Ottoman novel by the authors under consideration. In this section, I will trace these depictions and focus on how while Samipaşazade Sezai, Ahmet Mithat and Halit Ziya like to depict the tragic lives of passive slave girls, Fatma Aliye derives empowerment even from slavery. ${ }^{40}$ The approaches of the first three authors reflect a choice to depict tragicized and caricatured situations to create strong emotions in the public, out of which an effort to change them is hoped to grow. Slavery is one such instance; ignorant mothers - the anti-muse of reading-children described above in the context of

\footnotetext{
36 As used by Deleuze and Guattari, A Thousand Plateaus, 9-10.

37 Braidotti, "Becoming Woman."

38 Deleuze and Guattari, $A$ Thousand Plateaus, 276.

39 "The girl is like the block of becoming that remains contemporaneous to each opposable term, man, woman, child, adult. It is not the girl who becomes a woman; it is becoming-woman that produces the universal girl" (Deleuze and Guattari, A Thousand Plateaus, 277).

40 Also see Feryal Saygılıgil, "Anneliğin Osmanlı romanında kurgulanışı," Toplum ve Bilim, 126, Şubat 2013, 144-161.
} 
children's newspapers and journals - are another. Slavery and ignorant mothers combine to produce deadly scenarios.

Namık Kemal, for example, mentions slavery less, while developing the theme of ignorant mothers more. ${ }^{41}$ Intibah [Awakening] (1876) is his first novel, and is presented as Sergüzeşt-i Ali Bey [The Life story of Mr Ali]. This is also the life story of the slave girl Dilaşub, whose tragedy is detailed more fully in novels by Halit Ziya, Ahmet Mithat and Samipaşazade Sezai analysed below. She is the slave whom Fatma, Ali's mother, buys to redirect Ali's interest from Mahpeyker, another woman much more experienced in love than Ali. Fatma is an example of an ignorant woman who manipulates lives via the buying and selling of slaves. When Dilaşub fulfils her duty, she is resold on the slightest doubt of here taking an interest in another man. She is submissive and silent even though she is the most scrupulous character. In fact, she is a rare character among women and men who are weak even when they are depicted as good. But in the end she is the one who pays the price for the weaknesses of others. However, Namık Kemal compensates for the lack of good female characters in Intibah with Zekiye in an earlier work, a play titled Vatan yahut Silistre [Homeland or Silistria] (1873). The work features the story of Zekiye (feminine name for 'Clever'), who becomes a woman by first becoming a boy: her love interest, Islam, leaves her to defend the fortress of Silistria castle in the Crimean War against the Russians. Instead of waiting passively, Zekiye disguises herself as a boy, joins Islam's forces and, despite being the youngest in this troop, takes part in the bravest and the cleverest moves against the enemy. Being able to protect Silistria enables Islam and Zekiye's union, and it turns out that Zekiye's long-lost father was the commander of the castle. She saves the castle, the homeland, Islam and her father all at once by being disguised as a boy. ${ }^{42}$ In this story, which became a trigger for Turkish nationalism, motherland and the girl are adjacent concepts. They are both in the process of becoming: for the motherland to come into being, she has to be valued and everything else sacrificed for her worth. For Zekiye to become a woman, and hold on to the man she loves, she has first to become a boy. This way she can win back her father as well! Thus processes of becoming feed on each other, and all feed on the capacities of girlhood, yet this is disguised and Zekiye's girlhood becomes invisible in her desire and her pseudo-boyhood. Whereas Dilaşub is a side character in Intibah, other novels — and plays like Homeland — will be built on girls as their main characters. In fact, male writers' focusing on and sympathizing with slave

41 Namık Kemal, “Aile," in Mustafa Nihat Özön (ed.) Namık Kemalve İbret Gazetesi (İstanbul: Remzi Kitabevi, 2003), 19-205.

42 Namık Kemal, Vatan yahut Silistre (İstanbul: Tumrul Şirket Matbaası, 1291 [1872]). 
girls and their lives from childhood to womanhood becomes a persistent theme in the birth of the Ottoman novel. However, like Zekiye's powerful girlhood, this trait has not been emphasized so far. ${ }^{43}$

In Ahmet Mithat's Felatun Bey ile Rakım Efendi (1875), ${ }^{44}$ the rich and whimsical dandy Felatun is contrasted with the poor but smart Rakım. However, the main twist of the story is revealed in the life of Canan, a slave girl bought and raised by Rakım. Rakım tutors Canan, like he educates British girls living in Istanbul —or like Ahmet Mithat educates Fatma Aliye: he is motherly, tender and compassionate to all, both in real life and writing in fiction. In mothering Canan, Rakım creates a well-mannered, beautiful woman out of an uneducated slave girl and marries her. Ahmet Mithat finishes his novel with Rakım, who tutors students and his future wife, as the winner as against Felatun, who ends up poor and miserable.

The slave girl theme is continued with Halit Ziya's (1866-1945) first novel. While the former three writers were more political in nature, Halit Ziya aimed at a more literary form rather than a political form of writing. ${ }^{45}$ However, his first novel was not among the high-quality works that he would soon produce. In Sefile [The Miserable] (1886-1887), ${ }^{46}$ Halit Ziya tells the adventures of the slave girl Mazlume (feminine name for 'Oppressed'). Evil women come her way, as well as good women. Both are ideal types, and so is Mazlume. As a child her misery increases even with goodness, as she has to return to evil households after enjoying the good ones. Her story of becoming woman is sealed by falling in love. The combination of love and slavery result in prostitution, Mazlume's wild slaying of the love and enemy of her life, and her own death. While her girlhood carries a potential for freedom despite all the combined negative aspects of slavery, her passage into womanhood by falling in love for Halit Ziya means a death.

In Sergüzeşt [Life story or Adventure] (1888), Samipaşazade Sezai (1859-1936) develops the same themes of love, slavery, misery and death. Under the strong influence of Namık Kemal, he tells in his only novel the story of another slave girl, Dilber. Dilber's story is more aesthetically tragic, and in her person slavery

43 I focused on Namık Kemal's play as he is also a novelist. However, Ahmet Hamdi Tanpınar rightly points to the potentials of evaluating the plays of Abdülhak Hamit as well. Ahmet Hamdi Tanpınar, Ondokuzuncu Asır Türk edebiyatı tarihi (İstanbul: İ.Ü. Edebiyat Fakültesi Yayınları, 1949).

44 Ahmet Mithat, Felatun Bey ile Rakım Efendi (İstanbul: Özgür Yayınları, 2003 [1875]).

45 Nurdan Gürbilek, Kör Ayna, Kayıp Şark; Edebiyat ve Endişe (İstanbul: Metis Yayınları, 2004).

46 Halit Ziya, Sefile [The Miserable] (İstanbul: Özgür Yayınları, 2006 [1886-1887]). 
is more openly condemned than the story of Sefile. In Sergüzeşt, Dilber, too, is bought and sold from one family to another, and in the meantime she transforms herself from a young girl to a young woman. This change is depicted with a change in her beauty: she changes from a weak, sickly girl into an attractive, sparkling young woman. However, ironically, while being weak and girly will protect her from wanted and unwanted sexual advances, her beauty and passage to womanhood will prove to be a fatal combination with slavery, and her love will draw her to suicide. In the house where she arrives as an attractive young woman, the young man first ignores and mocks her and then starts painting her picture, manipulating her like his toy. She rebels and cries and he sees that she is in fact a human being. And they fall in love. However, his mother, the lady of the house, sells Dilber in the market to prevent the love between a slave and a lord.

\section{Women's Stories of Girls}

The theme of love between a slave and a lord took a very different turn in the hands of Fatma Aliye. However, before going into details about her novel Muhâdarât (1891-1892), ${ }^{47}$ it is worth surveying the slave girl theme in her other novels. For example, in her novel Refet (1897), ${ }^{48}$ she imagines a public school as an alternative to both poverty and marriage. Here Fatma Aliye depicts the life of Refet, who clings to the processes of public schooling, rather than marriage, to escape her poverty. Refet can be considered a feminist utopia where girls and women can exist without much reference to men. Furthermore, by dismissing marriage, this book transforms the aim of the modern state in creating a new type of family. Fatma Aliye is more interested in the new woman, and refuses to see her as a tool for creating this family.

In Refet, women's support of girls is important to Refet's story of her transformation from a poor, ugly, unhealthy child into a strong, independent woman who does not need to be pretty. Refet, by becoming a teacher when she graduates, turns around and supports these informal spheres - and not an idealized, modern, nuclear family - with the means she derives from the practice of public education. Thus, girls and women use public education, itself a product of patriarchy, to resist patriarchy through informal women's spheres. Fatma Aliye transforms the main theme of the Ottoman novel, girlhood, via Refet, proving

47 Fatma Aliye, Muhâdarât (İstanbul: Enderun Kitabevi, 1996 [1891-1892]).

48 Ead., Refet (İstanbul: L Yayıncılık, 2007 [1897]). 
that even practices of public education can become something other than patriarchy when their relation to informal spheres is acknowledged.

Upon the death of her father while she is a young child, Refet and her mother lose everything, including their home, and are left without any allowances. However, despite the hardships they have to endure, Refet perseveres in her studies and becomes a teacher. She is then able to save the women who surround and support her during times of hardship. By the time she graduates from the teachers' college [Darülmuallimat], she has transformed the average turn-of-the-century Istanbul family into a world of women strengthened by the ties of sisterhood, motherhood, friendship and neighbourhood.

On graduation, Refet is ready to realize her true potential as a teacher. Unlike many characters in post-Tanzimat novels, she accepts herself as a poor, unattractive young woman. More importantly, she recognizes the fact that neither a husband nor a school can provide the intuition that one develops when surrounded with the perseverance of women in need. When Refet's mother dies when she is about to graduate, her good friend Şule - as poor, as smart and as desolate as she is-reminds her of the greatness of God. ${ }^{49}$ In this thought they unite, and fulfil their aims of self-sufficiency. Refet's story demonstrates that it is indeed possible to 'become women' together.

Aliye tells a similar story in Enin [Lamentations] (1910), ${ }^{50}$ another tale in which two young women 'become women' together. However, the childhood and girlhood of the main character, Sabahat, is only a small part of that novel. Two of the main characters are slave girls: İtimat, Sabahat's best friend and confidante, and Piraye. Piraye's life is tragically similar to Namık Kemal's Dilaşub, as even though she grows up in the safety of a good family, she falls in love with her young master Rifat, while Rifat falls in love with Fehame. Piraye dies of a broken heart. İtimat shares a similar fate even though it is not as heavily emphasized as Piraye's: Whereas they grew up together with Sabahat, the protagonist, Sabahat, in her search for a good husband, ends up being more and more interested in their neighbor Fehame and in a way grows away from İtimat in their collective search for science instead of marriage! In Muhadarat [Memorable Stories / Useful Information] Fatma Aliye reverses the slave-girl theme by choosing as her protagonist an unhappy, rich and married woman who chooses to be a slave. Slavery gives Fazlla a chance to be a girl again, not knowing what will happen to her, not knowing what the limits of slavery will be. She leaves her riches and power as a woman behind to be like a girl again.

49 Fatma Aliye, Refet, 188.

50 Fatma Aliye, Enin [Lamentations] (İstanbul: Boğaziçi Üniversitesi Yayınları, 2005 [1910]). Also see Firdevs Canbaz, Fatma Aliye (İstanbul: Timaş Yayınları, 2010). 
Thus, although the slave girl theme is left behind in this novel, slavery and girlhood become almost synonymous, both deriving the ultimate power to be and to become from powerlessness.

After Fatma Aliye's Muhadarat and before her Enin, in 1900, Halit Ziya (Uşaklıgil) (1866-1945), published his famous novel Aşk-ı Memnu [Forbidden Love], which developed the themes of love between a slave boy and the girllady, and between another boy and this girl and her stepmother. Its main characters include the young orphan girl Nihal and her little brother Bülent, whose wealthy father marries the attractive Bihter. Bihter's beauty and spell start to transform Nihal from a child into a woman, but soon she discovers that they love the same man, Behlül. Nihal then turns back to being daddy's little girl and this time, in contrast to other male novelists who saw the death of girlhood in becoming a woman, it is not girlhood, but womanhood that dies in the person of Bihter.

This novel can be evaluated under the heading Women's Stories of Girls because, as Nurdan Gürbilek has suggested, Halit Ziya "becomes" his famous femme fatale Bihter, the young woman who marries the rich man in this novel. ${ }^{51}$ Thus Halit Ziya stands in between male and female writers. It is not Ahmet Mithat but Halit Ziya who in this sense, to again refer to Deleuze and Guattari, "not imitating or assuming the female form, but emitting particles that enter the relation of movement and rest, or the zone of proximity, of a microfemininity." ${ }^{22}$ He surpasses the death of the girl by facing and embracing this fear. ${ }^{53}$

Nihal's commitment to childhood is resolved in Halide Edip's Handan (1912) ${ }^{54}$ Halide Edip, too, lost her mother at a young age; she wrote more than twenty-five novels and has had a deep impact on Turkish literature. Towards the middle of the book, we go back to the girlhood of her autobiographic character Handan. She is educated in science and life by an older man, who is soon conjoined by a younger revolutionary. She becomes a woman when she falls in love with this man. Halide Edip similarly married one of her private tutors, Salih Zeki, at the age of seventeen while she was still at school. However, the man Handan marries is not her mentor, the man she falls in love with, but an older man who values her when she behaves as a woman, wearing make-up, dressing in ways that emphasise décolletage, acting mysteriously. When she is her real self, though, he ignores her, not even realizing that she is around.

\footnotetext{
51 Gürbilek, Kör Ayna.

$5^{2}$ Deleuze and Guattari, $A$ Thousand Plateaus, 276.

53 Gürbilek, Kör Ayna.

54 Halide Edip Handan (İstanbul: İkbal Kitabhanesi, 1342 [1924]).
} 
She is like a shadow then. Handan's crisis is learning womanhood from men who do not value the sets of knowledge related to being a woman, instead valuing women for their enthusiasm - for a 'male' knowledge - and beauty. The enthusiasm lies in their ongoing girlhood and beauty in becoming women. While Handan's husband caricatures these expectations (and Halide Edip's real-life mathematician husband Salih Zeki), her first teacher and love interest also shares these traits. Yet unlike Nihal, under a French education Handan is allowed to grow up and become a woman. She is then able to get even with her husband and everything he represents: she falls in love with another man, who is again a revolutionary but who values women as they are. However, she knows this because he is the husband of her almost-sister and best friend Neriman, whom he cannot love as she had never had an interest in male knowledge. Thus, Handan dies out of guilt.

\section{The Empire Strikes Back}

At the time of the passage from empire to republic, in 1922, came the most popular example of a bildungsroman: Çalıkuşu, by Reşat Nuri (Güntekin) (1889-1956), who has acknowledged his open admiration of for Fatma Aliye's novels. ${ }^{5}$ Çalıkuşu [The Wren] is a nickname for Feride, an orphan who loses first her father-like Refet — and then her mother-unlike Refet. Feride grows up first in her aunt's mansion and then in a missionary school in Istanbul. Her girlhood is extended, as she falls in love with a relative, but is unable to unite with him throughout the novel. She leaves Istanbul, works at various posts in Anatolia during the war years, and adopts another young orphan girl, Munise, in one of these posts. Only then does she grow up, and in mothering Munise she manages to withstand the pain of being all alone. This time the story of the girl, which continued in womanhood with Bihter and Neriman, finds expression with Munise, and only after her death does Feride unite with her long-lost lover.

In Çalıkuşu, the Ottoman girl grows up into a woman during the war years that created the Turkish Republic. However, the story of the Ottoman girl did not end with Güntekin. As Tanpınar states in his History of the Nineteenth Century Novel, the themes that are left from previous generations are developed again and again, and this is how literature develops. ${ }^{56}$ Halide Edip developed the themes of girlhood and becoming woman par excellence in one of her

55 Reşat Nuri (Güntekin), Çalıkuşu (İstanbul: İkbal Kitabevi, 1935).

$5^{6}$ Tanpinar, Ondokuzuncu asır. 
best-known novels, Sinekli Bakkal [The Clown and His Daughter, which is not a direct translation of the title]. Yet although this novel takes place in the Hamidian era, it was published in 1935, after the passage to the Republic in 1923. The heroine, Rabia, grows up with divided allegiances to her deceased mother's well-off and religious family and her revolutionary father who has an underground théâtre des atelier under his shop in a poor district. She is loved dearly by both sides and everyone else who comes into her life. She loves them back. Thus, she carries religion and revolution, the Quran and music, richness and poverty with her all at once. She embodies the all-encompassing characteristics of girlhood. She finally combines them and becomes a woman when she falls in love with an aged Italian man, her music teacher, who marries her after converting to Islam. ${ }^{57}$

\section{Conclusion}

The bildungsroman that takes a character from her childhood into her grownup years is a widespread genre in the Ottoman novel. Both the slave girl stories and stories of education - which sometimes collide, as in Ahmet Mithat's works - commonly focus on girls growing up. The complicated passage from girlhood to womanhood entails tragedy, growth and rebirth. For example, and in contrast to the slave girl theme that gave birth to the Ottoman novel, Rabia's and Refet's stories transform the tragic fate suited to girls by nationalist writers. Their stories do not end with tragic deaths as an indicator of the male authors' vision that equates womanhood with the death of girlhood. However, in women's and Halit Ziya's stories, passages between girlhood and womanhood are possible: Nihal and Fazıla both become women, but turn back into girlhood. Female writers manipulate the system subtly to change the fate of girls and extend the influence of their potential. However, as the nationalists felt fit to marginalize Fatma Aliye and Halide Edip into minoritarian positions, the nationalist resolution of women's problem was stuck in creating girls who did not grow up to be women. ${ }^{58}$ In short, both male and female writers used the girl and her processes of becoming woman to resist the Empire and create an idea of nationalism to encompass the needs of the masses. While women portrayed more genuine stories of becoming, the nation that was created out of these efforts dwelled largely on men's portraits

57 Halide Edip Adıvar, Sinekli Bakkal (İstanbul: Ahmet Halit Kitap Evi, 1936).

58 Aksu Bora, "Annesiz Kızlar: Modern Babaların Modern Kızları," Folklor ve Edebiyat, 61, 2010, 7-15; Elif E. Akşit, Kızların Sessizliği (İstanbul: İletişim Yayınları, 2012). 
of suffering girls. Thus, as I stated in the introduction, the birth of the novel, the birth of the nation and the birth of the girl can be thought of together, but in order for the first two to come into being from nothingness, the latter, the real, the genuine, should be manipulated and killed in men's novels. Although women present alternative stories and transform the faith of girlhood, these stories are again manipulated but, as with Rabia, retrospective interferences in the past are possible, like female writers making transformations between girlhood and womanhood possible. This chapter, in the Deleuzian interstices between literature, history and philosophy, also aims to be a minor effort for restarting such transformations.

\section{Bibliography}

\section{Primary}

Aliye, Fatma, Hayal ve Hakikat: Bir Kadın ve Ahmet Midhat, İstanbul: Ylldı Üniversitesi Basım Yayın, 2005 [1892].

Aliye, Fatma, Refet, İstanbul: L Yayıncılık, 2007 [1897].

Aliye, Fatma, Muhâdarât, İstanbul: Enderun Kitabevi, 1996 [1891-1892].

Aliye, Fatma, Hayattan Sahneler (Levayih-i Hayat), Istanbul: Boğaziçi Üniversitesi Yayınevi, 2002 [1897-1898].

Aliye, Fatma, Enin [Lamentations], İstanbul: Boğaziçi Üniversitesi Yayınlan, 2005 [1910].

Edip Adıvar, Halide, Sinekli Bakkal, İstanbul: Ahmet Halit Kitap Evi, 1936.

Edip Adıvar, Halide, Handan, İstanbul: İkbal Kitabhanesi, 1342 [1924].

Garnett, Lucy Mary Jane, The Women of Turkey and Their Folklore, London: D. Nutt, 1890-1891.

Kemal, Namık, Vatan yahut Silistre, İstanbul: Tumrul Şirket Matbaası, 1291 [1872].

Kemal, Namık, "Aile," in Mustafa Nihat Özön (ed.) Namık Kemal ve İbret Gazetesi, İstanbul: Remzi Kitabevi, 2003, 19-205.

Mithat, Ahmet, Felatun Bey ile Rakım Efendi, İstanbul: Özgür Yayınları, 2003 [1875].

Mithat, Ahmet, Bir Muharrire-i Osmaniye'nin Neşeti, İstanbul: İsis, 1998 [1893].

Nuri (Güntekin), Reşat, Çalıkuşu, İstanbul: İkbal Kitabevi, 1935.

Sırn, Selim, "Türk Kızının Öğüdü," Çocuk Duygusu, 6, 1912, 1.

Sırrı, Selim, "Kızlarıma Öğütlerim: Ben Neyim," Çocuk Duygusu, 19, Temmuz 1913, 1.

Tevfik, Baha, "Fransa İhtilalinden bir Sahife," Çocuk Duygusu, 1, 6 Haziran 1329 [1913], 1.

Tevfik, Baha, "The Humanist Feelings of a Child" [Bir Çocuğun İnsaniyetperveranesi],

Çocuklara Mahsus Gazete, 13 Şubat 1312 / 23 Ramazan 1314 [25 February 1897], 1.

Vaka Brown, Demetra, Haremlik, Boston: Houghton Mifflin Company, 1909.

Ziya, Halit, Sefile [The Miserable], İstanbul: Özgür Yayınları, 2006 [1886-1887]. 


\section{Secondary}

Abdullah, Thabit, Merchants, Mamluks, and Murder: The Political Economy of Trade in Eighteenth Century Basra, Albany: State University of New York Press, 2001.

Adak, Hülya, "Gendering Biography: Ahmet Mithat (on Fatma Aliye) or the Canonization of an Ottoman Male Writer," Querelles, 10, 2005, 189-204.

Akpolat-Davud, Yıldız, "II. Meşrutiyet'te Toplumda Kadına Başat Rol Vermeyen: Kadın Dergisi Mahasin," Tarih ve Toplum, 156, Aralık 1996, 362-367.

Akşit, Elif E., "Girls' Education and the Paradoxes of Modernity and Nationalism in the Late Ottoman Empire and the Early Turkish Republic," unpublished PhD thesis, Binghamton University, Department of History, 2004.

Akşit, Elif E., "Harem Education and Heterotopic Imagination," Gender and Education, 23 (3), 2011, 299-311.

Akşit, Elif E., Kızların Sessizliği, İstanbul: İletişim Yayınları, 2012.

Akyüz, Yahya "Osmanlı Son Döneminde Kızların Eğitimi ve Öğretmen Faika Ünlüer’in Yetişmesi ve Meslek Hayatı," Millî Eğitim 143, 1999, 19.

Altınay, Ayşe Gül, The Myth of the Military-Nation: Militarism, Gender and Education in Turkey, New York: Palgrave Macmillan, 2004.

Ariès, Philippe, A Social History of Family Life, London: Jonathan Cape, 1962.

Azim, Mehmet, "Çocuk Bahçesi Dergileri," Müteferrika, 19, 2001, 143-179.

Baron, Beth, Egypt as a Woman: Nationalists, Gender, and Politics, Berkeley: University of California Press, 2005.

Blom, Ida, Karen Hagemann and Catherine Hall (eds), Gendered Nations: Nationalisms and Gender Order in the Long Nineteenth Century, Oxford: Berg Publishers, 2000.

Bora, Aksu, "Annesiz Kızlar: Modern Babaların Modern Kızları," Folklorve Edebiyat, 61, 2010, 7-15.

Braidotti, Rosi, "Becoming Woman: Or Sexual Difference Revisited," Theory, Culture \& Society, 20 (3), 2003, 43-64.

Bruneau, Marie Florine, "Learned and Literary Women in Late Imperial China and Early Modern Europe," Late Imperial China, 13 (1), 1992, 156-172.

Buchanan, Ian and Claire Colebrook (eds), Deleuze and Feminist Theory, Edinburgh: Edinburgh University Press, 2000.

Canbaz, Firdevs, Fatma Aliye, İstanbul: Timaş Yayınları, 2010.

Davin, Anna, "Imperialism and Motherhood," History Workshop, 5, 1978, 9-65.

Davis, Fanny, The Ottoman Lady: A Social History from 1718 to 1918, New York: Greenwood Press, 1986.

Deleuze, Gilles and Felix Guattari, A Thousand Plateaus: Capitalism and Schizophrenia II, translated by Brian Massumi, Minneapolis: University of Minnesota Press, 1987.

Doumani, Beshara, Rediscovering Palestine: Merchants and Peasants in Jabal Nablus 1700-1900, Berkeley: University of California Press, 1995.

Ellison, Grace Mary, An Englishwoman in a Turkish Harem, London: Methuen and Co., 1915. 
Fattah, Hala, The Politics of Regional Trade in Iraq, Arabia, and the Gulf, 1745-1900, Albany: State University of New York Press, 1997.

Fortna, Benjamin C., "Learning to Read in the Late Ottoman Empire and Early Turkish Republic," Comparative Studies of South Asia, Africa and the Middle East, 21 (1-2), 2001, 34-41.

Gürbilek, Nurdan, Kör Ayna, Kayıp Şark; Edebiyat ve Endişe, İstanbul: Metis Yayınları, 2004.

Hathaway, Jane, The Politics of Households in Ottoman Egypt: the Rise of the Qazdagli, Cambridge: Cambridge University Press, 1997.

Koven, Seth and Sonya Michel (eds), "Womanly Duties: Maternalist Politics and the Origins of Welfare States in France, Germany, Great Britain, and the United States, 1880-1920," American Historical Review, 95 (4), 1990, 1092-1093.

Koven, Seth and Sonya Michel, Mothers of a New World: Maternalist Politics and the Origins of Welfare States, London: Routledge, 1993.

Mardin, Şerif, The Genesis of Young Ottoman Thought: A Study in the Modernization of Turkish Political Ideas, Syracuse, NY: Syracuse University Press, 2000.

Mitchell, Sally, The New Girl: Girls' Culture in England 1880-1915, New York: Columbia University Press, 1995.

Peirce, Leslie, The Imperial Harem: Women And Sovereignty In The Ottoman Empire, New York: Oxford University Press, 1993.

Saygılıgil, Feryal, "Anneliğin Osmanlı romanında kurgulanışı," Toplum ve Bilim, 126, Şubat 2013, 144-161.

Sotirin, Patty, "Becoming-woman," In Charles J. Stivale (ed.), Gilles Deleuze: Key Concepts, Durham, UK: Acumen, 2005, 98-109.

Tanpınar, Ahmet Hamdi, Ondokuzuncu Asır Türk edebiyatı tarihi, İstanbul: İ.Ü. Edebiyat Fakültesi Yayınları, 1949.

Varlık, Bülent, “Tanzimat ve Meşrutiyet Dergileri," Tanzimat'tan Cumhuriyet'e Türkiye Ansiklopedisi, (İstanbul: İletişim Yayınları, 1985).

Weismann, Itzchak and Fruma Zachs (eds), Ottoman Reform and Muslim Regeneration, London: I.B. Tauris, 2005.

Zürcher, Erik J., Turkey: A Modern History, London: I.B. Tauris, 2004. 